\title{
MUTUALLY CONSISTENT CLASSIFICATION SCHEMES FOR MANTLE-DERIVED GARNET AND CHROMITE, FOR USE BY DIAMOND EXPLORERS
}

\author{
Herman Grütter ${ }^{1}$ and Andrew Menzies ${ }^{2}$ \\ ${ }^{I}$ Mineral Services Canada, Vancouver, Canada ${ }^{2}$ Mineral Services South Africa, Cape Town, South Africa
}

\section{INTRODUCTION}

Exploration techniques for kimberlites and lamproites worldwide may involve many multi-disciplinary approaches. One fairly standard approach is to trace mantle-derived garnet, chromite and related indicator minerals to their source. The pathfinder minerals are routinely analysed for major and minor elements by electron microprobe, in part to identify and differentiate them from visually similar minerals of non-mantle origin, but also to enable qualitative predictions to be made regarding the diamond potential of their source rock. Garnet and chromite are the minerals of choice in this application since they are commonly found as inclusions in diamond and prove to have quite distinct compositions. This compositional association with diamond has been used over the past 30 years to construct a number of indicator mineral classification schemes of varying complexity, statistical rigour and diamond-predictive capacity. Currently available published data for mantle xenoliths, phase-equilibrium experiments and heavy mineral concentrates from diamondiferous and barren kimberlites indicate that certain "diamond-inclusion"-type garnet and chromite compositions may also occur in association with graphite, and hence that an update of the mineral classification schemes used during diamond exploration is in order. Here we formulate a simple but effective garnet classification scheme that carries forward many concepts from previous workers (e.g. Gurney and Switzer, 1973; Sobolev et al., 1973; Switzer, 1975; Dawson and Stephens, 1975; Gurney, 1984; Schulze, 1997; Grütter and Anckar, 2003; Schulze, 2003) and updates them in the light of empirical, petrologic and thermobarometric data for mantle-derived xenocrysts and xenoliths. Further work, to be reported at the 8IKC, will involve cross-correlating the garnet groups defined here with the compositions of coexisting chromite in xenoliths, thereby defining a chromite classification scheme which is internally consistent with that proposed here for garnet.

\section{DATA AND METHODS}

\section{DATA}

Compositional data for garnet and chromite occurring in concentrate from kimberlites and related rocks, in mantle xenoliths and as inclusions in diamond were compiled from many published sources and unpublished theses. These are too numerous to list here, but are outlined in our acknowledgements. The analyses were checked for "reasonable" stoichiometry and screened to eliminate rare non-mantle (i.e. crustal) compositions. Garnets showing > 3.1 Si cations per 12 oxygens (i.e. majoritic) occur only as inclusions in diamonds and are not considered further.

\section{PRESSURES AND TEMPERATURES}

Xenolith thermobarometry techniques and the diamond stability field of Kennedy and Kennedy (1976) were used to separate peridotite samples into graphite-stable or diamond-stable portions of the mantle. The requisite pressures and temperatures were calculated using the orthopyroxene-garnet barometer of Nickel and Green (1985) in combination with a clinopyroxene-solvus thermometer (Nimis and Taylor, 2000) for lherzolites and either the olivine-garnet (O'Neill and Wood, 1979, preferred) or orthopyroxene-garnet (Harley, 1984) thermometer for garnet harzburgites. The thermobarometric calculations cannot be applied directly to the individual garnet and chromite grains typically recovered in diamond exploration programs, but indirect application of the P-T results can be made by assuming that a typically cratonic geotherm pertains to the area being explored, and by adopting an empirical approach which compares and contrasts garnet and chromite compositions from sources that are known to be diamondiferous or barren. This assumption and approach is central to our classification scheme, implying that it is calibrated for diamond-stable conditions at mantle temperatures exceeding 950 to $1000^{\circ} \mathrm{C}$, these being equivalent to the 38 to $40 \mathrm{~mW} / \mathrm{m}^{2}$ model conductive geotherms of Pollack and Chapman (1977). Individual grains that can be associated with 


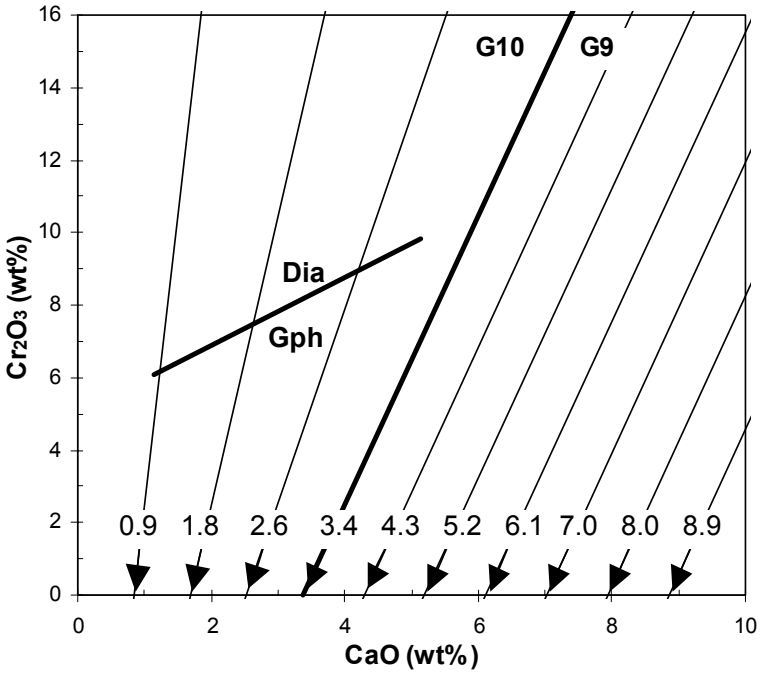

Figure 1: Conventional garnet $\mathrm{Cr} 2 \mathrm{O} 3$ vs. $\mathrm{CaO}$ diagram showing the G10 / G9 divide of Gurney (1984) and the graphite-diamond constraint of Grütter and Sweeney (2000). The downward-pointing arrows with CA_INT values illustrate the geometric effect of the calcium-intercept projection to 0 wt \% Cr2O3 (after Grütter and Anckar, 2003).

diamond under these assumptions are labeled with the suffix " $A$ " in our scheme, while those associated with a graphite are denoted with the suffix "B". Application of this nomenclature requires verification of the assumed geotherm, by way of a mineralogical orientation survey.

\section{USEFUL CALCULATIONS}

The $\mathrm{CaO}$ and correlated $\mathrm{Cr} 2 \mathrm{O} 3$ variations displayed by mantle garnets in harzburgitic, lherzolitic and wehrlitic assemblages may be summarised with a continuous variable by a simple geometric projection to a calciumintercept value at $0 \mathrm{wt} \% \mathrm{Cr} 2 \mathrm{O} 3$ (denoted CA_INT as in Fig. 1). CA_INT values are given by (oxides in wt $\%$ )

\section{IF $\mathrm{CaO} \leq 3.375+0.25 * \mathrm{Cr} 2 \mathrm{O} 3$ \\ THEN CA INT $=13.5 * \mathrm{CaO} /(\mathrm{Cr} 2 \mathrm{O} 3+13.5)$ ELSE CA_INT $=\mathrm{CaO}-0.25^{*} \mathrm{Cr} 2 \mathrm{O} 3$.}

Instead of using $\mathrm{FeO}$ or $\mathrm{MgO}$ in our classification schemes, we prefer to use $\mathrm{Mg} /(\mathrm{Mg}+\mathrm{Fe})$ ratios on an $\mathrm{Fe} 2 \mathrm{O} 3$-free basis, and calculate these as

\section{MGNUM $=(\mathrm{MgO} / 40.3) /(\mathrm{MgO} / 40.3+\mathrm{FeOt} / 71.85)$.}

We also make use of the graphite / diamond constraint defined by chromite+garnet+carbon assemblages in peridotite samples derived from cratonic geotherms (see Grütter and Sweeney, 2000). The constraint falls within the field of harzburgitic garnet compositions at
$\mathrm{Cr} 2 \mathrm{O} 3=5.0+0.94 * \mathrm{CaO}$
(see Fig. 1).

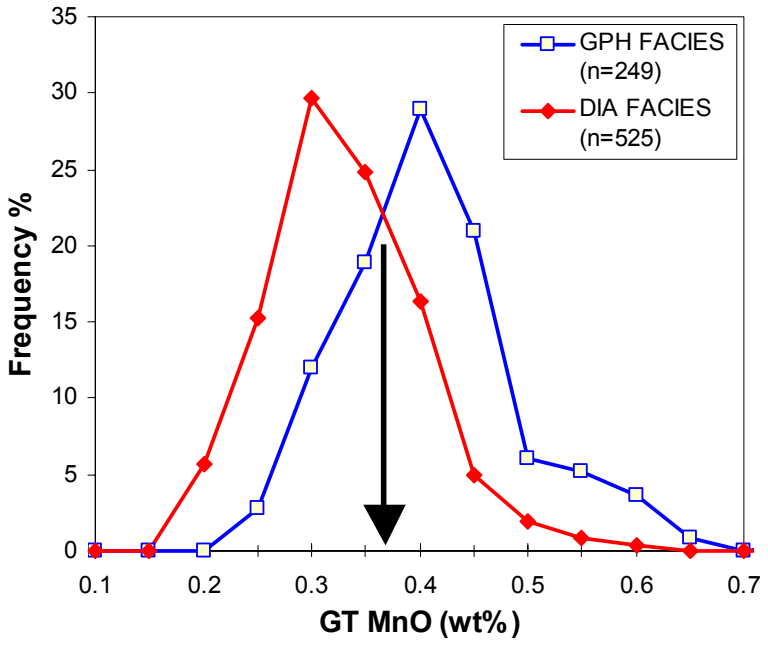

Figure 2: Histogram summarizing the $\mathrm{MnO}$ contents of peridotitic garnets in diamond or graphite associations. These associations overlap somewhat within the range 0.25 to 0.5 $\mathrm{wt} \% \mathrm{MnO}$, but we adopt a crude division at $0.37 \mathrm{wt} \% \mathrm{MnO}$ (arrow) for the purposes of this work. Diamond-associated garnets are those included in diamond, occurring in diamondbearing peridotite samples, or having calculated P-T conditions inside the diamond stability field. Graphiteassociated garnets occur in graphite-bearing peridotite samples or have calculated P-T conditions within graphite stability.

\section{GARNET CLASSIFICATIONS}

\section{HARZBURGITIC (G10)}

Gurney (1984) correlated $85 \%$ of peridotitic garnet inclusions in diamonds from global sources with the Ca-poor, Cr-rich pyrope Cluster 10 of Dawson and Stephens (1975), and in doing so "branded" the G10 garnet standard with which the diamond potential of exploration projects is often judged (Fig. 1). It is now known that certain lower-Cr G10 garnet compositions may occur in graphite-bearing harzburgite xenoliths (e.g. Nixon et al., 1987; Viljoen et al., 1994; Grütter and Sweeney, 2000) and we denote these compositions with the suffix "B" in our classification scheme. By contrast, diamond-associated garnet compositions are denoted by the suffix "A". The Cr-saturation characteristics of G10 garnets (Fig. 1) and/or their $\mathrm{MnO}$ content (Fig. 2) may be used to differentiate graphiteassociated from diamond-associated compositions. G10 garnets in our classification scheme are thus compositionally characterised by

$\mathrm{Cr} 2 \mathrm{O} 3[\mathrm{wt} \%]: \quad 1$ to $<22$

CA_INT [wt\%]: 0 to $<3.375$ (by definition)

MGNUM: $\quad \geq 0.75$ to $\leq 0.95$

G10A diamond-associated garnets additionally have

$\mathrm{Cr} 2 \mathrm{O} 3 \geq 5.0+0.94 * \mathrm{CaO}$, or

$\mathrm{Cr} 2 \mathrm{O} 3<5.0+0.94 * \mathrm{CaO}$ and $\mathrm{MnO} \leq 0.37$.

G10B graphite-associated garnets additionally have $\mathrm{Cr} 2 \mathrm{O} 3<5.0+0.94 * \mathrm{CaO}$ and $\mathrm{MnO}>0.37$. 


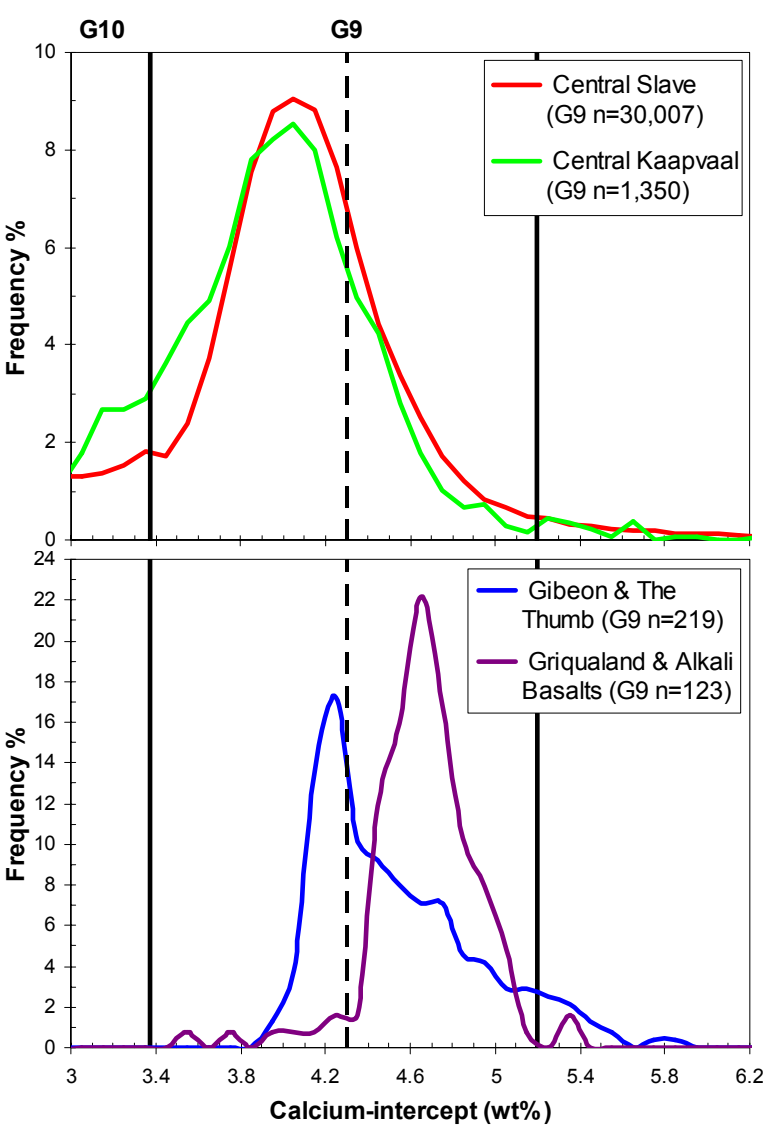

Figure 3: Histograms of CA_INT values for Cr-pyrope garnets with $\mathrm{Cr} 2 \mathrm{O} 3>1.0 \mathrm{wt} \%$ from diamondiferous cratonic settings (top) and barren, mainly off-craton settings (bottom). These relationships suggest CA_INT values $>4.3$ indicate sampling of low-pressure lherzolite. Upper diagram based on data in Grütter and Anckar (2003); lower diagram based on published data for peridotite xenoliths from many sources. Note that CA_INT $<5.2$ forms a natural upper calcic limit for lherzolitic garnets from a wide variety of settings.

\section{LHERZOLITIC (G9)}

Moderately calcic Cr-pyrope garnets derived from lherzolites are often by far the most abundant garnet type recovered in diamond exploration applications. Their statistical association with diamond is weak $(15 \%$ of peridotitic inclusions in diamond, based on Gurney, 1984), particularly given their high relative abundance as xenocrysts in diamondiferous kimberlites. Garnet lherzolite xenoliths may occur inside the stability fields of graphite or diamond on cratonic geotherms, and the $\mathrm{MnO}$ contents of their garnets may again be used to crudely separate these associations (Fig. 2). It is additionally known from empirical observations on garnet concentrates from economic on-craton and barren off-craton kimberlites, that the $\mathrm{CaO}$ content of lherzolitic Cr-pyrope garnet populations is inversely proportional to pressure (e.g. Boyd and Gurney, 1982). The relationship is well known from high-pressure experimental results, where it is found to be non-linear and most useful as a relative barometer at pressures inside the graphite stability field (see Brey et al., 1990). The relatively calcic nature of low-pressure lherzolitic garnets is observed empirically to correspond with CA_INT values greater than 4.3 (Fig. 3), and we treat such values as effectively indicating, on a statistical basis, derivation of garnet lherzolite from the graphite stability field. The CA_INT data available indicate an upper limit of 5.2 is reasonable for garnet in lherzolitic assemblages (Fig. 3). Dawson and Stephens (1975) classified lherzolitic garnets in cluster 9, and in our scheme G9 garnets have the following compositions

$\mathrm{Cr} 2 \mathrm{O} 3[\mathrm{wt} \%]: \quad>1.0$ to $<20$

CA_INT [wt $\%$ ]: $\geq 3.375$ to $<5.2$

MGNUM: $\quad \geq 0.7$ to $\leq 0.89$

G9A diamond-associated garnets additionally have

$\mathrm{Cr} 2 \mathrm{O} 3 \geq 5.0+0.94 * \mathrm{CaO}$, or

CA_INT $<4.3$ and $\mathrm{MnO} \leq 0.37$.

G9B graphite-associated garnets additionally have

CA_INT $\geq 4.3$ or $\mathrm{MnO}>0.37$.

\section{MEGACRYSTIC (G1)}

Garnets belonging to the megacryst suite may occur in relative abundance in certain kimberlites, but they are also occasionally found in other mantle-derived magmas like "melnoites" and certain alkali basalts. Megacrystic garnets are commonly coarse-grained (2$10 \mathrm{~cm}$ ) and significantly fractured, so they are often represented by disproportionately abundant dispersed pathfinder grains that are found during exploration activities. Isolating them as a specific compositional group is thus important from an exploration perspective, even though megacrysts have no established association with diamond and diamondstable P-T conditions cannot easily be deduced from their compositions. Megacrysts have $\mathrm{Cr}, \mathrm{Ca}$ and $\mathrm{Mg}$ number characteristics quite similar to pyroxenitic garnets, but the latter garnets mostly are less titaniferous at any given $\mathrm{Mg}$-number (see below). Garnet megacrysts correspond very closely to cluster group 1 of Dawson and Stephens (1975) and we characterise their compositions as having

$\mathrm{Cr} 2 \mathrm{O} 3[\mathrm{wt} \%$ ]: $\quad 0$ to $\leq 5.0$

CA_INT [wt $\%$ ]: 3.5 to $\leq 6.0$

MGNUM: $\quad \geq 0.55$ to $\leq 0.86$

$\mathrm{TiO} 2[\mathrm{wt} \%]: \quad>(\mathrm{MGNUM}+0.25) / 2.75$

$\mathrm{TiO} 2[\mathrm{wt} \%]: \quad<2.4$.

\section{ECLOGITIC (G3)}

Diamond-bearing eclogite xenoliths are known to have in-situ grades equivalent to 1,000 to 20,000 carats per 
tonne, and for this reason alone eclogitic garnets represent extremely important pathfinder minerals for diamond explorers. Eclogitic garnets are aluminous and show large variations in $\mathrm{FeO}, \mathrm{MgO}$ and $\mathrm{CaO}$, to the extent that Dawson and Stephens (1975) required five separate cluster groups to circumscribe their compositional variation (their groups 3, 4, 5, 6 and 8). A detailed compilation of garnet compositions in carbon-free and carbonaceous eclogites shows that carbon is not preferentially associated with eclogitic garnets of particular Fe-Mg-Ca composition (see Fig. 1 of Grütter and Quadling, 1999). This implies that subdivision of eclogitic garnets on the basis of variable $\mathrm{FeO}, \mathrm{MgO}$ or $\mathrm{CaO}$ content provides little real leverage for the diamond explorationist and we accordingly choose to define Group 3 eclogitic garnets as a single category across a range of compositions, as follows:

$\mathrm{Cr} 2 \mathrm{O} 3[\mathrm{wt} \%]$ : 0 to $\leq 1.0$

CA_INT $[\mathrm{wt} \%]: \geq 2.0$ to $\leq 32.0$

MGNUM: $\quad \geq 0.17$ to $\leq 0.86$

$\mathrm{TiO} 2[\mathrm{wt} \%]: \leq 1.0$.

Eclogitic garnet inclusions in diamond are known to commonly have $\mathrm{Na} 2 \mathrm{O}>0.07 \mathrm{wt} \%$ (e.g. McCandless and Gurney, 1989), though the discrimination from graphite-bearing eclogite on the basis of this criterion alone is not unique (Grütter and Quadling, 1999). Further research into this relationship may yet reveal a distinct compositional separation of diamond-associated from graphite-associated eclogitic garnet and hence provide the basis for subdividing this garnet category into groups $\mathrm{G} 3 \mathrm{~A}$ and $\mathrm{G} 3 \mathrm{~B}$, following the convention established above.

\section{PYROXENITIC (“G4”)}

Dawson and Stephens (1975) did not classify garnets that occur in pyroxenitic (or websteritic) mantle lithologies into a specific group, but included them within their G9 lherzolitic and G3 eclogitic categories, principally because pyroxenitic garnets show compositional overlap with those garnet types. Pyroxenitic garnets were also left undifferentiated in a recent garnet classification scheme (Schulze, 2003), but their importance to exploration has been highlighted via a distinct diamond association by Aulbach et al. (2002), and from the point of view of lithospheric evolution by Pokhilenko et al. (1999). We have thus sought to compositionally differentiate pyroxenitic / websteritic garnets and found them to be characterised by:
$\mathrm{Cr} 2 \mathrm{O} 3[\mathrm{wt} \%$ ]: 0 to $\leq 5.0$
CA_INT [wt $\%$ ]: 3.5 to $\leq 6.5$
MGNUM: $\quad \geq 0.3$ to $\leq 0.86$
$\mathrm{TiO} 2[\mathrm{wt} \%]: \leq(\mathrm{MGNUM}+0.25) / 2.75$

These compositional limits are in some respects similar to G9 lherzolitic garnets, G1 megacrystic garnets, and also to common G3 eclogitic garnets (see above). We nevertheless retain the pyroxenitic garnet category and label it "G4" by default, noting that this nomenclature departs slightly from the titaniferous ferroan eclogitic garnet category originally envisioned by Dawson and Stephens (1975).

\section{DISCUSSION}

The classification scheme outlined above utilizes a few relatively simple criteria to categorize common mantlederived garnets into seven compositional groups, based only on their major and minor element concentrations, as determined by industry-standard electron microprobe analysis. Inclusion of an eighth category to accommodate the G11 high-TiO2 peridotitic garnet cluster of Dawson and Stephens (1975) may be justified, and a ninth category could be reserved for garnets that default in the current classification. In implementing the current scheme it is considered prudent to test an unknown for compositional compliance in the strict order G1, followed by G4, then G3, then G10 and lastly G9. These compositional categories are similar to those defined by earlier workers, but the current scheme differs substantially in its' application by emphasizing garnets that are geochemically and thermodynamically related to diamond. Cross-validation of the garnet groups with chromite compositions will occur in due course and these results will be reported at the $8 \mathrm{IKC}$.

\section{ACKNOWLEDGEMENTS}

The mineral composition data published or compiled and supplied by John Gurney, Eva Anckar, the Kimberlite Research Group at the University of Cape Town, Dave Bell, Gerhard Brey, Joe Boyd, Barry Dawson, Leander Franz, Don Francis, Agnes Fung, Andrei Girnis, Chris Hatton, Richard Hervig, Dmitri Ionov, Bruce Jago, Melissa Kirkley, Tom McCandless, Roger Mitchell, Peter Nixon, Norman Pearson, Graham Pearson, Nick Pokhilenko, Kevin Quadling, Roberta Rudnick, Dan Schulze, Simon Shee, Doug Smith, Nick Sobolev, Thomas Stachel, Johan Stiefenhoffer, Fanus Viljoen, Bruce Wyatt are gratefully acknowledged. 


\section{REFERENCES}

Aulbach, S., Stachel, T., Viljoen, K.S., Brey, G.P., Harris, J.W., 2002. Eclogitic and websteritic diamond sources beneath the Limpopo Belt - is slab-melting the link? Contrib. Mineral. Petrol., 143, 56-70.

Brey, G., Köhler T., Nickel, K.G. (1990) Geothermobarometry in four-phase lherzolites I. Experimental results from 10 to $60 \mathrm{~kb}$. J. Petrol. 31, 1313-1352.

Boyd, F.R., Gurney, J.J., 1982. Low-Calcium garnets: Keys to craton structure and diamond crystallization. Carnegie Inst. Wash. Yearbook 81, 261-267.

Dawson, J.B., Stephens, W.E., 1975. Statistical classification of garnets from kimberlite and associated xenoliths. J. Geol. 83, 589-607.

Grütter, H.S., Anckar, E., 2003. $\mathrm{Cr}-\mathrm{Ca}$ and related characteristics of central Slave and central Kaapvaal craton mantle pyropes, with implications for diamond and graphite in peridotite. Accepted in Special Issue of Lithos.

Grütter, H.S., Quadling, K.E., 1999. Can sodium in garnet be used to monitor eclogitic diamond potential ? In: Gurney, J.J., Gurney, J.L., Pascoe, M.D., Richardson, S.H. (Eds.), J. B. Dawson volume, Proceedings of the 7th International Kimberlite Conference, Red Roof Design, Cape Town, 314-320.

Grütter, H.S., Sweeney, R. J., 2000. Tests and constraints on single-grain Cr-pyrope barometer models: some initial results. In: GeoCanada 2000 Extended Abstracts, GAC/MAC Annual Joint Meeting, Calgary, April 2000.

Gurney, J.J., 1984. A correlation between garnets and diamonds. In: Glover, J.E., Harris, P.G. (Eds.), Kimberlite occurrence and origins: a Basis for Conceptual Models in Exploration. Geology Department and University Extension, University of Western Australia, Publication 8, 143-166.

Gurney, J.J., Switzer, G.S., 1973. The discovery of garnets closely related to diamonds in the Finsch pipe, South Africa. Contrib. Mineral. Petrol. 39, 103-116.

Harley, S. L., 1984. An experimental study of the partitioning of $\mathrm{Fe}$ and $\mathrm{Mg}$ between garnet and orthopyroxene. Contrib. Mineral. Petrol. 86, 359-373.

Kennedy, C.S., Kennedy, G.C., 1976. The equilibrium boundary between graphite and diamond. J. Geophys. Res. 81, 2467-2470.

McCandless, T.E., Gurney, J.J., 1989. Sodium in garnet and potassium in clinopyroxene: criteria for classifying mantle eclogites. In: Ross, J. (Ed.) Kimberlites and related rocks. Geological Society of Australia Special Publication 14/2, 827-832.

Nickel, K.G., Green, D.H., 1985. Empirical geothermobarometry for garnet peridotites and implications for the nature of the lithosphere, kimberlites and diamonds. Earth Planet. Sci. Lett. 73, 158-170.
Nimis P. and Taylor W. R., 2000. Single clinopyroxene thermobarometry for garnet peridotites. Part 1 . Calibration and testing of a Cr-in-Cpx barometer and an enstatite-in-Cpx thermometer. Contrib. Mineral. Petrol. 139, 541-554.

Nixon, P.H., van Calsteren, P.W.C., Boyd, F.R., Hawkesworth, C.J., 1987. Harzburgites with garnets of diamond facies from southern African kimberlites. In: Nixon, P.H. (Ed.) Mantle Xenoliths. Wiley and Sons, 523-533.

O'Neill, H.S.C., Wood, B. J., 1979. An experimental study of Fe-Mg partitioning between garnet and olivine and its calibration as a geothermometer. Contrib. Mineral. Petrol. 70, 59-70.

Pokhilenko, N.P., Sobolev, N.V., Kuligin, S.S., Shimuzu, N., 1999. Peculiarities of distribution of pyroxenite paragenesis garnets in Yakutian kimberlites and some aspects of the evolution of the Siberian craton lithospheric mantle. In: Gurney, J.J., Gurney, J.L., Pascoe, M.D., Richardson, S.H. (Eds.), P. H. Nixon volume, Proceedings of the 7th International Kimberlite Conference, Red Roof Design, Cape Town, 689-698.

Pollack, H.N., Chapman, D.S., 1977. On the regional variation of heat flow, geotherms, and lithospheric thickness. Tectonophysics 38, 279-296.

Schulze, D.J., 1997. The significance of eclogite and Cr-poor megacryst garnets in diamond exploration. Explor. Mining Geol. 6, 349-366.

Schulze, D.J., 2003. A classification scheme for mantlederived garnet in kimberlite: A tool for investigating the mantle and exploring for diamonds. Accepted in Special Issue of Lithos.

Sobolev, N.V., Lavrent'yev, Y.G., Pokhilenko, N.P., Usova, L. V., 1973. Chrome-rich garnets from the kimberlites of Yakutia and their paragenesis. Contrib. Mineral. Petrol. 40, 39-52.

Switzer, G.S., 1975. Composition of garnet xenocrysts from three kimberlite pipes in Arizona and New Mexico. Smithsonian Contrib. Earth Sci. 9, 1-21.

Viljoen, K.S., Robinson, D.N., Swash, P.M., Griffin, W.L., Otter, M.L., Ryan, C.G., Win, T.T., 1994. Diamondand graphite-bearing peridotite xenoliths from the Roberts Victor kimberlite, South Africa. In: Meyer, H.O.A., Leonardos, O.H. (Eds.) Proc. Fifth Int. Kimb. Conf., Vol 1: Kimberlites, related rocks and mantle xenoliths. CPRM Spec. Publ. 1A/94, 285-303.

Contact: H. S. Grütter, Mineral Services Canada, \#1300 - 409 Granville Street, Vancouver, B.C., V6N 1T2, Canada. Email: herman.grutter@mineralservices.com 